ら，撮影の位置決めの安定化も欠くことのできない要素 である。その観点からも両演題共，簡易化された補助具 の開発で，良効な結果が得られていると思う。

2）自動露出

演題534は断層に於ける自動露出では,管電圧制御によ る撮影と管電圧一定による撮影で㹥写真のコントラスト に与える影響は(東芝，安原氏質問)，アルミステップで の撮影では変化は認められたが，臨床例では顕著な差は 認められず実際の撮影には影響はなかった（応答）。

また，管電圧の変化に伴う線量との相関々係をイオト マートの出力波形で調べ検討を加えたかどうか（札幌， 後藤氏質問) の提言があった。検討の方法は如何にせよ, 断層における露出の自動化に伴いマニュアル撮影時との 患者への照射線量の変化はどうか検討の余地がある.

演題535は受光部の位置が副鼻腔部に設定されている が，慢性副鼻腔炎等の経過観察を必要とする病栄の変化 に伴う写真濃度のバラツキは診断に影響を与える縣念が あると思われるが(福岡，寒竹氏質問)，副鼻腔低部の描 出を促すために敢えて, 受光部の位置を副鼻腔部に設定 した (応答).

また，受光部の位置関係により Base Beiw の撮影で は，自動露出装置の使用が不可能になっている。この部 位の撮影は，露出の定めにくい所でもあり，自動化を望 みたいところである。

演題536は試作品によると, バックルファイバを 0.25 $\mathrm{mm} \phi, 140$ 本使用で $3 \mathrm{~m}, 400$ 本使用で $10 \mathrm{~m}$ 迄長さを延長 でき, 光の減弱率も $70 \%$ と, 受光部の薄さも加え, 十分 実用に值するものと思われる。

3）装置の開発

演題537はとかく能率本位の昨今の医療体制の中で, 患 者（特に小児）に与える精神的動摇を減少させる装置の 開発は有意義に思う。特に小监撮影では被嚗の問題から 再撮影の減少，および付添者数の減少は好ましい結果に なっている。

演題578は速写部内での IP プレートの流れに対する 時間配分（日立，池田氏質問）の提示はなかったが，サ イクルタイム（撮影終了から次回フィルムセットアップ 迄の時間）は， 7 秒と従来の装置と大差はない。そして 当装置の効率，省力化は具体的には何を意味するか（日 立，池田氏質問)。これはIP プレートを使用したカセッ テ撮影よりは，速写性が良く，省力化されている(応答) という意味合いのものである.

次にフィルム上に写真として描出する迄に要する時間 は (三重, 石岡さん質問)，読取り装置の性能如何に左右
されるが，現時点では 3 分である．これは当装置では online 化されて扔らず，撮影済みのIP プレートを取り 出してから読み取り装置への搬送の時間は含まれていな い(応答)。将来，読取り装置との online 化㧍よび，処理 時間の短縮を望みたい。

当装置は，これからの X 線装置の一指針を示す装置の 1 つかと思われ，今後の発展を期待する。

\section{R1-15 心筋}

座長 中田 茂（愛媛大学医学部附属病院放射線部）

540. ${ }^{201} \mathrm{Tl}$ 心筋シンチの基礎的検討

島根医科大学医学部附属病院放射線部

○笠井俊文・氏平武樹・高橋司伸 小松明夫・君野勝治

雑種犬を用いて ${ }^{201} \mathrm{Tl}$ による心筋局所血流量, 梗塞範 囲について基礎的検討を行った。

局所血流量は $\mathrm{r}=0.97$ と大変良い相関を示し, ${ }^{201} \mathrm{~T} 1$ 心 筋 SPECT 像は局所血流量を正しく反映しているといえ る. SPECT 像は血流量が50〜 60\%に減少すると欠損像 として現われ，20\%前後の血流変化も認識でき虚血性心 疾患の評価に有用である.臨床との比較でも core と梗塞 部，border と一過性虚血部の血流量が良く一致した。

梗塞範囲の推定を ROI 法により行った。この方法は ROI 設定時の cut level や梗塞に関係しない血流の存在 などの誤差要因はあるが $\mathrm{r}=0.88$ と良い相関を示し，梗 塞範囲の推定法として有効と思われる.

\section{1. 運動負荷 ${ }^{201} \mathrm{Tl}$ 心筋シンチグラフィーの評価一再 分布の妥当性について一 \\ 埼玉医大病院放射線科 \\ ○小川 清・加藤知明・折原悦子 伊勢谷修・小川 武・山崎節雄 吉田 正・山口和弘 関根茂夫 関 守雄}

〔目的〕負荷 ${ }^{201} \mathrm{~T} 1$ 心筋シンチグラフィーに拉ける ${ }^{201} \mathrm{Tl}$ の心筇初期集積は投与量の $4 \sim 5 \%$ 足らずであり 残りの 95〜96\%は他臟器に分配される。この時，心筋以 外の ${ }^{201} \mathrm{~T} 1$ の動態を無視して心筋再分布を評価してよい ものか検討した。

〔結果〕 血中カウント, 心筋，心筋外臟器の 3 コンパ 一トメント解析を試みたが全身像では定量的評価はでき なかった。しかしながら急速な心筋への取り込みや心筋 からのクリアランス（ $\mathrm{Tl} / 2=3.2 \mathrm{hr}$.), ${ }^{201} \mathrm{Tl}$ 血中濃度や 全身像カウントの変動の少なさから再分布の妥当性が証 明された。 